\title{
Analisis Karakteristik Kunci Yang Mempengaruhi Kualitas Audit
}

\author{
Wiwi Idawati \\ Sekolah Tinggi Ilmu Ekonomi Indonesia (STEI) - Jakarta \\ Email: wiwiidawati@ymail.com
}

\begin{abstract}
The aim of this research was to get the empirical evidence about the effect of professionalism, integrity, and audit fee on quality audit. This research uses causalcomparative method with primary data that acquired from the distribution of questionairres. The research population was 255 Public Accounting Firm (KAP) in DKI Jakarta are registed at IAPI, and sample in this research was 41 Public Accounting Firm (KAP) in DKI Jakarta, with a simple random sampling technique. Researcher managed to collect 177 respondents from 41 Public Accounting Firm (KAP). Data analysis was used multiple linear regression. Based on the research, variable professionalism, integrity, and audit fee variable have simultaneously effect on quality audit.
\end{abstract}

Keywords: Profesionalism, Integrity, Audit Fee and Quality Audit.

\begin{abstract}
Abstrak: Tujuan penelitian ini adalah untuk memperoleh bukti empiris pengaruh profesionalisme, integritas, dan fee audit terhadap kualitas audit. Penelitian ini menggunakan metode penelitian kausal-komparatif dengan data primer yang diperoleh dari penyebaran kuesioner. Populasi dalam penelitian ini adalah 255 Kantor Akuntan Publik di DKI Jakarta yang terdaftar di IAPI dan Sampel dalam penelitian ini adalah 41 Kantor Akuntan Publik (KAP) di DKI Jakarta, dengan teknik sampling simple random sampling. Peneliti berhasil mengumpulkan responden sebanyak 177 responden dari 41 KAP. Analisis data dilakukan menggunakan regresi linier berganda. Berdasarkan penelitian ini, variabel profesionalisme, integritas, dan fee audit berpengaruh secara simultan terhadap kualitas audit.
\end{abstract}

Kata Kunci: Profesionalisme, Integritas, Fee Audit, dan Kualitas Audit.

\section{PENDAHULUAN}

Profesi akuntan publik memiliki peranan penting dalam melakukan audit laporan keuangan dalam suatu organisasi dan merupakan profesi kepercayaan masyarakat. Dari profesi akuntan publik, masyarakat mengharapkan penilaian yang bebas dan tidak memihak terhadap informasi yang disajikan oleh manajemen perusahaan dalam laporan keuangan (Mulyadi,2011). Mengingat bahwa laporan akuntansi diperlukan oleh masyarakat luas, maka kualitas laporan akuntansi tersebut menjadi sangat krusial. Sebelum laporan keuangan diterbitkan oleh manajemen sebagai alat pertanggungjawaban kepada para pemangku kepentingan, perlu ada jaminan bahwa laporan keuangan tersebut telah disajikan secara wajar. Yang paling tepat untuk memberikan ini adalah pihak di luar manajemen yang kompeten dan independen. Pihak ini sering disebut sebagai akuntan publik, yang fungsi pokoknya melakukan pemeriksaan umum atas laporan keuangan perusahaan sebelum diterbitkan sebagai alat pertanggungjawaban manajemen. (Agoes dan Ardana, 2013, p154). 
Menurut Arens et al. (2011) sebelumnya, para profesional diharapkan memiliki kepatutan dalam berperilaku yang lebih tinggi dibandingkan dengan kebanyakan orang pada umumnya.Auditor sebagai seorang profesional, harus menyadari adanya tanggung jawab kepada publik, klien, dan kepada rekan seprofesi, termasuk perilaku terhormat bahkan jika hal tersebut berarti harus melakukan pengorbanan atas kepentingan pribadi. Alasan adanya harapan yang begitu tinggi pada penerapan etika profesi bagi para profesional adalah pada dasarnya merupakan kebutuhan akan kepercayaan publik dalam kualitas pelayanan yang diberikan oleh para profesional.Para akuntan diwajibkan untuk memelihara kepercayaan publik dan menumbuhkan rasa tanggung jawab yang tinggi untuk menjaga kepercayaan publik. Bila publik mulai meragukan kompetensi seorang profesional dalam menjalankan profesinya, maka bisa berakibat publik tidak lagi memercayai kinerja seorang profesional tersebut sehingga dengan sendirinya publik tidak lagi memberi mandat atau kewenangan kepada yang bersangkutan dalam menjalankan profesinya (Agoes 2009, p163). Integritas dapat diukur dalam bentuk apa yang benar dan adil. Dalam hal tidak terdapat aturan, standar, panduan khusus atau dalam menghadapi pendapat yang bertentangan, anggota harus menguji keputusan atau perbuatannya dengan bertanya apakah anggota telah melakukan apa yang seorang berintegritas akan lakukan dan apakah angota telah menjaga integritas dirinya. Integritas mengharuskan anggota untuk menaati baik bentuk maupun jiwa standar teknis dan etika. Mulyadi,( 2002: 56).

Menurut Boo dan Koh (2004), dalam lingkungan audit, fee audit Seiring dihubungkan dengan kompetensi auditor dan hubungan ini saling terkait secara timbal balik. Kompetensi seorang auditor akan mempengaruhi fee yang mereka minta, disisi lain klien-klien juga hannya mau membayar fee audit yang lebih tinggi kepada perusahaan audit yang memiliki auditor yang kompeten dan mempunyai nama baik. Bagi klien kompetensi seorang auditor sangat berguna dalam memenuhi harapan-harapan klien terhadap hasil audit yang lebih berkualitas. Behn dkk, (1999) menemukan adanya suatu hubungan yang penting antara kepuasan klien dengan kompetensi auditor dan fee audit. Stanley dan DeZoort (2007), juga menemukan bahwa kompetensi auditor berhubungan positip terhadap fee audit. Menurut Lee (2004) jika auditor dengan klien sama-sama memiliki ukuran yang relative kecil, maka ada probabilitas yang besar bahwa penghasilan auditor akan menjadi tergantung pada fee audit yang dibayarkan oleh kliennya,oleh karena itu auditor kecil ini akan cenderung tidak independen terhadap kliennya.

Menurut Mills (1993), profesionalisme seorang auditor dapat dilihat dengan kompetensi yang dimilikinya maka pekerjaan auditor dapat berjalan dengan baik, sesuai standar pemeriksaan yang berlaku. De Angelo (1981) mendefinisikan kualitas audit sebagai probabilitas dimana seorang auditor menemukan dan melaporkan tentang adanya suatu pelanggaran. Beatty (1989) menyatakan kualitas audit sebagai ketelitian dari informasi yang disampaikan auditor. Sedangkan Wallace (1980), menyatakan bahwa kualitas audit merupakan suatu ukuran dari kemampuan auditor untuk menemukan kekeliruan dan bias serta memperbaiki kemurnian data dalam akuntansi.

Menurut Meidiawati (2011), dalam prakteknya fenomena berebut klien antara akuntan publik sebenarnya sejak dulu telah mewarnai perdagangan jasa audit, hal ini erat sekali dengan fee. Perhitungan fee audit didasarkan atas negosiasi dengan klien. Klien bisa saja memaksa akuntan publik untuk mengeluarkan opini seseuai dengan keinginan klien. Padahal seharusnya opini yang dikeluarkan auditor berdasarkan hasil pengumpulan bukti yang kompeten dan mencukupi, agar dapat memberikan pendapat tentang kewajaran laporan keuangan klien. Menurut Arens dkk, (2010:124), untuk membantu para akuntan 
publik mempertahankan objektivitas dalam melaksanakan audit akan memberikan imbal jasa atas dasar hasil dari jasa yang diberikan. De Angelo (1981) menemukan bahwa lowballing cost terjadi pada awal penugasan audit, hal ini terjadi karena situasi fee audit yang tidak dipublikasikan secara terbuka didepan publik. Pendapat ini didukung oleh Etteredge et al (2007) menyatakan bahwa pada awal penugasan audit di Amerika Serikat dengan situasi dimana fee auditor tidak dipublikasikan secara terbuka didepan publik mengandung lowballing cost. Praktik lowballing muncul ketika auditor menetapkan imbalan jasa audit yang murah dengan tujuan untuk memenangkan kontrak, dan berharap untuk menutup imbalan jasa audit awal dengan memberikan jasa lainnya pada klien atau dengan cara menaikan imbalan jasa auditnya diperiode mendatang (Arens 2011).

\section{KAJIAN TEORI}

Profesionalisme. Beberapa definisi terkait dengan profesionalisme, antara lain menurut Baotham (2007) profesionalisme auditor mengacu pada kemampuan dan perilaku professional. Kemampuan didefinisikan sebagai pengetahuan, pengalaman, kemampuan beradaptasi, kemampuan teknis, kemampuan teknologi, dan memungkinkan perilaku profesional auditor untuk mencakup faktor-faktor tambahan seperti transparansi dan tanggung jawab, hal ini sangat penting untuk dapat memastikan kepercayaan publik.

Menurut Heyrani et al (2015, p180), menyatakan "profesionalisme berhubungan dengan perilaku professional seseorang, tujuan, karakteristik dan fitur. fitur utama Profesi tenaga akuntansi adalah kompetensi, ketidakberpihakan dan kesetiaan. Tindakan dan perilaku anggota profesi tenaga akuntansi didasarkan pada persyaratan dan peraturan perilaku profesional yang dikembangkan oleh Asosiasi akuntansi profesional". Sedangkan menurut Sihotang (2016, p64), professional adalah memiliki kemampuan teknis dan operasional yang diterapkan secara optimum dalam batas-batas etika profesi.

Profesionalisme adalah sebuah konsep untuk mengukur bagaimana para profesional memandang profesi mereka yang tercermin melalui sikap dan perilaku mereka sebagai seorang auditor. Profesionalisme merupakan salah satu syarat yang harus dipenuhi dan dimiliki oleh seorang auditor dimana hal ini akan berdampak kepada sikap serta keteguhan di dalam menjalankan profesi sebagai auditor independen. (Yendrawati 2008, p76). Profesionalisme berarti auditor wajib untuk melaksanakan tugas-tugasnya dengan kesungguhan dan kecermatan. Sebagai seorang yang professional, auditor harus menghindari kelalaian dan ketidakjujuran Friska (2012). Kemudian menurut penelitian Lesmana dan Nera (2016, p36), mengatakan bahwa profesionalisme terdiri atas beberapa indikator, yaitu menggunakan pengetahuan dalam proses pengauditan, tetap teguh pada profesi yang dikerjakan. Sementara di dalam Standar Profesional Akuntan Publik (SPAP, 2011) seksi 150 menyatakan prinsip perilaku profesional mewajibkan setiap praktisi untuk memenuhi setiap ketentuan hukum dan peraturan yang berlaku, serta setiap praktisi juga harus menghindari setiap tindakan yang dapat menurunkan reputasi profesi, dan menghindari melakukan perbandingan yang tidak didukung bukti terhadap hasil pekerjaan praktisi lain.

Integritas. Menurut Agoes dan Ardana (2013, p187), menjelaskan integritas berarti seorang akuntan harus bertindak tegas dan jujur dalam semua hubungan bisnis dan profesionalnya. Orang yang berintegritas berarti mempunyai keutuhan diri, seluruh bagian dirinya bekerja dengan baik dan berfungsi sesuai rancangan. Orang berkualitas demikian 
memiliki komitmen untuk bertindak sesuai dengan apa yang dikatakan. Orang tersebut juga menyelaraskan tindakannya dengan nilai-nilai mendasar dan keyakinan yang ia miliki, dan bekerja berdasarkan suara hatinya, serta hidup dalam kebenaran dan tidak mudah tergoda oleh rayuan-rayuan gomban yang menggiurkan. Kemudian juga memiliki keberanian untuk mempertahankan keyakinannya, dan rela untuk bertindak dan berbicara atas apa yang diketahui sebagai hal benar, berterus terang (Sihotang, 2016, p216).

Bouhawia et al $(2015$, p60), menyatakan "integritas merupakan hal yang penting bagi auditor untuk melakukan suatu tindakan. Integritas tidak hanya membutuhkan kejujuran tapi membutuhkan juga berbagai hal yang berhubungan dengan kualitas seperti keadilan, kejujuran, keberanian, kejujuran intelektual dan kerahasiaan. Integritas mensyaratkan bahwa auditor tidak boleh memiliki konflik kepentingan dengan pihakpihak tertentu. Konflik kepentingan tersebut dapat timbul dari beberapa faktor seperti pribadi dalam diri sendiri,keuangan, bisnis, pekerjaan dan hubungan lain dengan tim audi yang terlibat.

Sukriah et al (2009) mengatakan integritas merupakan kualitas yang melandasai kepercayaan publik dan merupakan patokan bagi anggota dalam menguji semua keputusannya. Sedangkan menurut Arens et al (2015, p113), integritas berarti tidak memihak dalam melakukan semua jasa, dan harus terbebas dari konflik kepentingan. Selanjutnya menurut Prasetyo dan Agus (2016, p581), indikator dari integritas terdiri dari bersikap jujur, berani, dan bertanggung jawab, dan bersikap bijaksana. Arens et al (2015, p113), mengatakan dalam pelaksanaan setiap jasa profesional, seorang anggota harus dapat mempertahankan objektivitas, dan integritas, bebas dari konflik kepentingan, dan tidak boleh dengan sengaja membuat kesalahan penyajian atas fakta atau menyerahkan penilaiannya kepada orang lain. Kemudian menurut Agoes dan Ardana (2013, p145), seorang auditor harus bersikap konsisten. Masih dalam Agoes dan Ardana (2013, p199), mengatakan seorang auditor juga harus dapat memegang rahasia pihak yang diperiksa.

Fee Audit. Menurut De Angelo (1981) menyatakan bahwa fee audit merupakan salah satu faktor yang mempengaruhi kualitas audit dengan mempertimbangkan beberapa faktor dalam penugasan audit, seperti: ukuran perusahaan klien (client size), kompleksitas jasa audit yang dihadapi auditor (audit complexity), risiko audit yang dihadapi auditor dari klien (audit risk), nama terkenal kantor akuntan publik yang melakukan jasa audit (The big eigth auditor ).

Dalam Kode Etik Akuntan Indonesia (SPAP, 2011) diatur hal-hal yang berhubungan dengan imbalan jasa profesional (fee Profesional), yang meliputi: besarnya fee anggota dapat bervariasi tergantung antara lain: risiko penugasan, kompleksitas jasa yang diberikan, tingkat keahlian yang diperlukan untuk melaksanakan jasa tersebut, struktur biaya KAP yang bersangkutan dan pertimbangan profesional lainnya. Anggota KAP tidak diperkenankan mendapatkan klien dengan cara menawarkan fee yang dapat merusak citra profesi. Turpen (1995) mengatakan bahwa variasi dalam biaya jasa audit tergantung faktor-faktor sebagai berikut: karakteristik klien yang dihubungkan dengan upaya dan risiko audit, Besarnya KAP klien bersedia membayar lebih mahal (premium) apabila audit dilakukan oleh big six firms.

Besacier et al (2007) meneliti faktor-faktor penentu fee audit di Francis, dan menemukan bahwa fee audit bergantung pada ukuran perusahaan, risiko audit dan kehadiran dari perusahaan The Big Four. Gerrald et al (1994) menyatakan bahwa ukuran perusahaan dan tingkat kerumitan yang dihadapi dalam mengaudit akan mempengaruhi 
fee audit. Jika perusahaan yang diaudit besar maka fee audit akan naik karena auditor akan bekerja lebih untuk menyelesaikan pekerjaannya. Simunic (1980) menyatakan bahwa fee audit ditentukan oleh besar kecilnya perusahaan (klien size), risiko audit dan kompleksitas audit. Pendapat ini didukung oleh Beattie et al (2001) menyatakan bahwa penetapan fee audit disektor voluntary dipengaruhi oleh ukuran, kompleksitas dan lokasi organisasi. Disamping itu Jubb et al (1996) menyatakan bahwa risiko bisnis klien dan risiko audit berhubugan dengan fee audit. Selanjutnya Jubb et al (1996) risiko audit meningkat maka secara otomatis akan terjadi pola kenaikan fee audit.

Berdasarkan Surat Keputusan Ketua Umum Institut Akuntan Publik Indonesia Nomor: Kep.024/IAPI/VII/2008 tentang kebijakan penentuan fee audit, dalam menetapkan imbalan jasa, anggota harus mempertimbangkan kebutuhan klien, Tugas dan tanggung jawab menurut hukum, independensi, tingkat keahlian (levels of expertise) dan tanggungjawab yang melekat pada pekerjaan yang dilakukan, serta tingkat kompleksitas pekerjaan, Banyak waktu yang diperlukan dan secara efektif digunakan oleh anggota dan stafnya untuk menyelesaikan pekerjaan dan. basis penetapan fee yang disepakati. Menurut Lee (2004) jika auditor dengan klien sama-sama memiliki ukuran yang relatif kecil, maka ada probabilitas yang besar bahwa penghasilan auditor akan menjadi tergantung pada fee audit yang dibayarkan oleh kliennya, oleh karena itu auditor kecil ini akan cenderung tidak independen terhadap kliennya. Hay et al (2002) menyatakan bahwa fee audit merupakan salah satu faktor dari reputasi akuntan publik, ukuran dari akuntan publik, profesional akuntan publik, keanggotaan pada organisasi profesi dan pendidikan.

Kualitas Audit. Menurut Arens et., al (2012), memberikan definisi kualitas audit adalah kemampuan auditor dalam mendeteksi kesalahan pada laporan keuangan dan melaporkannya kepada pengguna laporan keuangan. Peluang mendeteksi kesalahan tergantung pada kompetensi auditor dan keberanian auditor melaporkan adanya kesalahan pada laporan keuangan. Selanjutnya De Angelo (1981) menyatakan bahwa kualitas audit terdiri dari: (1) kualitas teknis; (20 kualitas jasa; (3) hubungan auditor-klien; dan (4) independensi. Untuk dimensi kualitas teknis, terdiri dari indikator: (a) reputasi; (b) kemampuan; dan (c) jaminan. Dimensi kualitas jasa terdiri dari indikator: (a) empati; (b) daya tanggap; dan (c) jasa non-audit; sedangkan dimensi hubungan auditor-klien, terdiri dari indikator: (a) keahlian; (b) pengalaman; dan (c) status. Dimensi independensi terdiri dari satu indikator yaitu objektivitas.

Jackson et al (2008) menyatakan bahwa kualitas audit terdiri dari dua sisi yaitu kualitas aktual dan persepsi kualitas. Selanjutnya Jackson et al (2008) menyatakan bahwa kualitas aktual menunjukan tingkat risiko terjadinya kesalahan material dalam laporan keuangan yang dapat dikurangi oleh auditor, sedangkan persepsi kuantitas menunjukan tingkat kepercayaan para pengguna laporan keuangan terhadap efektifitas auditor dalam mengurangi salah saji material dalam laporan keuangan yang dibuat oleh manajemen.

Palmrose (1984) mendefinisikan kualitas audit sebagai suatu tingkat kepastian atau jaminan. Schroeroeder et al (1986) hasil penelitian ini menyimpulkan bahwa lima faktor penting penentu kualitas audit, yaitu perhatian partner, dan manajer KAP dalam audit, perencanaan dan pelaksanaan, komunikasi tim audit dan manajemen klien, independensi anggota tim dan menjaga kemuntakhiran audit. Carcello (1992) menyatakan bahwa faktor yang mempengaruhi kualitas auadit adalah pengalaman, keahlian industri klien, responsif, ketaatan auditor kepada standar profesional akuntan publik.

Beatty (1989) menyatakan bahwa kualitas audit sebagai ketelitian dari informasi yang disampaikan auditor. Wallace (1980) menyatakan bahwa kualitas audit merupakan kekeliruan dan bias serta memperbaiki kemurnian data dalam akuntansi. Beattie et al (1995) melakukan survey terhadap direktur keuangan dari 210 perusahaan listing di United Kingdom. Hasilnya mengindikasikan 5 (lima) karakteristik kunci, yaitu integritas KAP, kompetensi teknik KAP, 
hubungan kualitas kerja dengan audit partner, reputasi KAP, sikap skeptis tim audit. Samelson et al (2006) melakukan survey persepsi kualitas audit terhadap 302 direktur finance, menemukan 6 (enam) dimensi kualitas audit, yaitu pengalaman auditor, keahlian auditor, respon yang baik terhadap klien, profesionalisme auditor keterlibatan pimpinan pelaksana, memahami sistem dan internal kontrol klien.

Boon et al (2008), menyatakan bahwa terdapat 14 atribut dalam kualitas audit yang terdiri dari: 1) experience; 2) industry expertise; 3) responsiveness; 4) technical competence; 5) independence; 6) due care; 7) quality commitment; 8) executive involvement; 9) field work conduct; 10) audit committee; 11) ethical standard; 12) skepticism;13) freshness of perpective; dan 14) individual responsibility.

Messier et al (2006) menyatakan standar auditing bertindak sebagai bimbingan untuk mengukur kualitas kinerja auditor. Standar auditing membantu memastikan bahwa audit laporan keuangan dilaksanakan secara mendalam dan sistematis yang menghasilkan kesimpulan yang andal. Setiap profesi selalu dikaitkan dengan kualitas layanan yang dihasilkannya, tidak terkecuali Akuntan Publik. Kualitas audit sangat penting untuk menyakinkan bahwa profesi bertanggungjawab kepada klien, masyarakat umum dan aturan-aturan. Kualitas audit tentu saja mengacu pada standar yang berkenaan dengan kriteria atau ukuran mutu pelaksanaan serta dikaitkan dengan tujuan yang hendak dicapai dengan menggunakan prosedur yang bersangkutan, (Boynton et al 2006). Duff (2004) melakukan penelitian yang tujuannya adalah mengidentifikasikan dimensi-dimensi kualitas audit, terdiri dari: kualitas teknis, kualitas jasa, hubungan auditor-klien, dan independensi. Kualitas teknis terdiri dari indikator: reputation, capability, dan assurance. Kualitas jasa terdiri dari indikator: emphaty, responsiveness, dan non audit service. Hubungan auditor klien terdiri dari indikator: expertise dan experience. Independensi terdiri dari indikator: obyektivity.

Paradigma Penelitian dan Perumusan Hipotesis. Berdasarkan uraian diatas, maka inti dari penelitian ini adalah bagaimana pengaruh profesionalisme, integritas, dan fee audit terhadap kualitas audit. Hal ini didukung dengan penelitian terdahulu yang menyatakan bahwa semakin tinggi sikap profesionalisme, integritas yang dimiliki auditor serta penetapan fee audit yang sesuai dengan SPAP maka kualitas audit yang dihasilkan oleh auditor akan semakin baik. Maka penulis dapat merumuskan hipotesis penelitian:

$\mathrm{Ho}_{1}$ : Profesionalisme tidak berpengaruh terhadap kualitas audit

$\mathrm{Ha}_{1}$ : Profesionalisme berpengaruh terhadap kualitas audit.

$\mathrm{Ho}_{2}$ : Integritas tidak berpengaruh terhadap kualitas audit.

$\mathrm{Ha}_{2}$ : Integritas berpengaruh terhadap kualitas audit.

$\mathrm{Ho}_{3}$ : Fee audit tidak berpengaruh terhadap kualitas audit

$\mathrm{Ha}_{3}$ : Fee audit berpengaruh terhadap kualitas audit.

$\mathrm{Ho}_{4}$ : Profesionalisme, Integritas, dan Fee audit secara simultan tidak berpengaruh terhadap kualitas audit.

$\mathrm{Ha}_{4}$ : Profesionalisme, Integritas, dan Fee audit secara simulta berpengaruh terhadap kualitas audit.

Hubungan akan hal ini digambarkan ke dalam paradigma penelitian: 


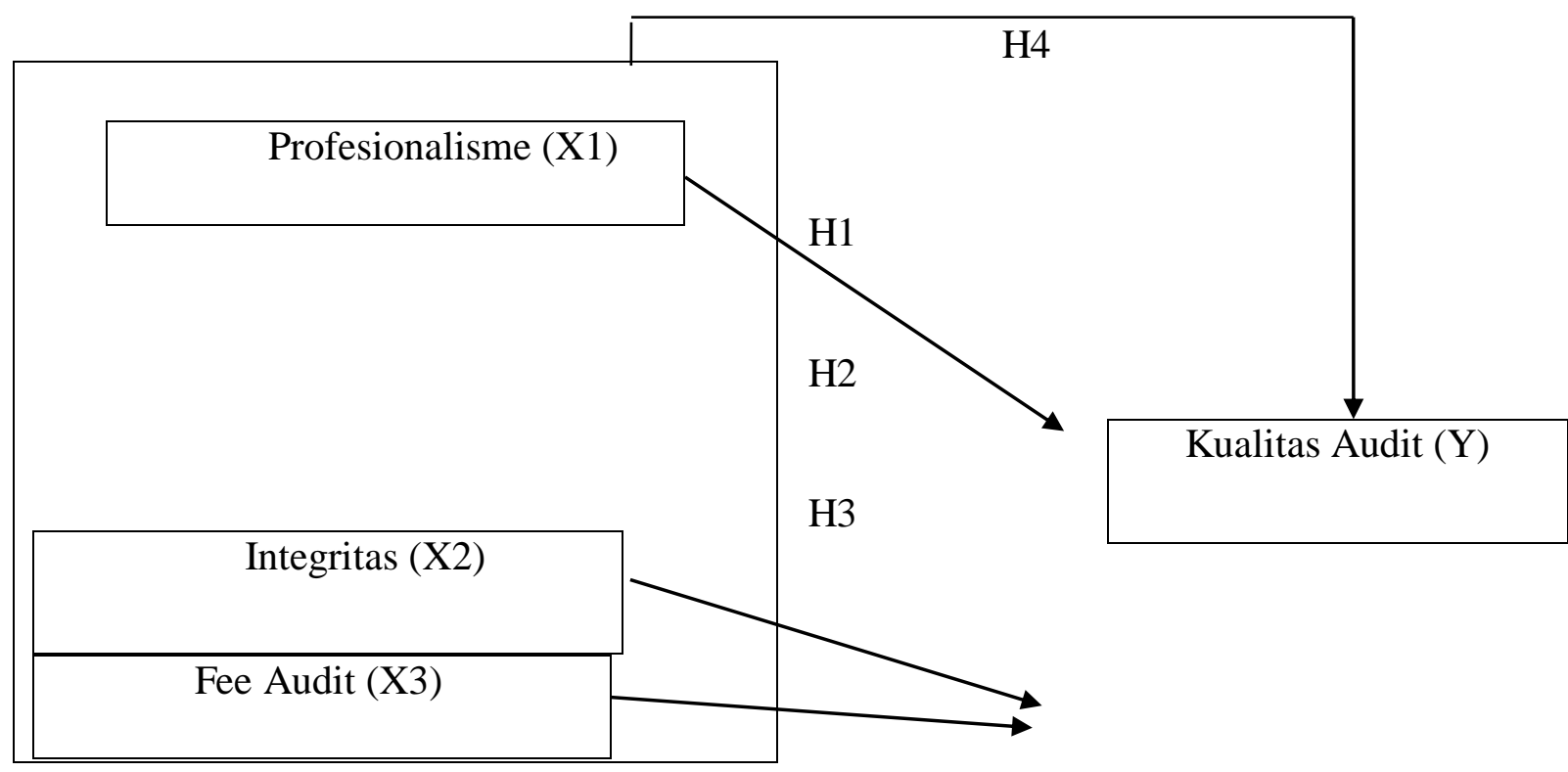

Gambar 1. Gambar Kerangka Pemikiran

Sumber: Hasil olahan peneliti (2017)

\section{METODE}

Subjek penelitian dalam penelitian ini adalah para auditor yang bekerja pada Kantor Akuntan Publik (KAP) di DKI Jakarta. Dalam penelitian ini Dalam penelitian ini yang menjadi objek penelitian terbagi menjadi dua variabel, yaitu variabel independen dan variabel dependen. Variabel independen penelitian ini memiliki objek penelitian berupa profesionalisme, integritas, dan fee audit, sedangkan variabel dependen penelitian ini memiliki objek penelitian berupa kualitas audit.

Penelitian ini merupakan penelitian kuantitatif. Sedangkan jenis penelitian yang digunakan dalam penelitian ini adalah penelitian kausal-komparatif yang termasuk dalam bagian penelitian asosiatif atau hubungan, yang bertujuan untuk mengetahui hubungan antara dua variabel atau lebih serta mengetahui pengaruhnya (Sujarweni, 2014, p11).

Populasi dan Sampel Penelitian. Peneliti menggunakan populasi dari Kantor Akuntan Publik (KAP) yang berada di DKI Jakarta. Sementara sampel dari penelitian ini adalah auditor yang bekerja pada KAP di DKI Jakarta. Pada tahun 2016, terdapat 255 KAP yang terletak di DKI Jakarta yang terdaftar dalam Institut Akuntan Publik Indonesia (IAPI).

Peneliti menggunakan teknik pengambilan sampel probability sampling dengan metode pengambilan sampelnya menggunakan simple random sampling. Hal ini berarti setiap KAP diberikan kesempatan yang sama dalam berpartisipasi mengisi kuesioner yang diajukan peneliti. Dalam penyebaran yang dilakukan, penulis berhasil mengumpulkan 41 sampel KAP yang bersedia menjadi responden dari penelitian ini dengan total 177 responden yang dapat diolah datanya.

Metode Analisis. Data yang digunakan adalah data primer yang diperoleh dari penyebaran kuesioner yang diberik bobot nilai 1-5 dengan hasil olahan menggunakan 
skala interval. Analisis dan pengolahan data yang dilakukan menggunakan aplikasi komputerisasi yaitu aplikasi SPSS 22.

Teknik uji validitas yang digunakan dalam penelitian ini adalah korelasi Pearson (Pearson Correlation) yaitu pengujian signifikansi dilakukan dengan kriteria nilai sig 2tail dari skor total $<0,05$ dan nilai $r$ hitung $>$ dari $r$ tabel 0,1476 dimana degree of freedom (df) $=177-3-1=173$ maka item dapat dinyatakan valid (Priyatno, 2016, p51-53). Sementara untuk uji reliabilitas peneliti menggunakan metode Cronbach's Alpha dengan batasan adalah 0,6 adalah kurang baik, sedangkan 0,7 dapat diterima dan diatas 0,8 adalah baik Sekaran dalam Priyatno (2016, p60). Kemudian untuk uji asumsi klasik dibagi menjadi uji normalitas dengan grafik p-plot, uji multikolinieritas dengan melihat nilai tolarence dan Variance Inflation Factor (VIF) pada model regresi, dan uji heteroskedastisitas dengan melihat metode korelasi Spearman's rho dan grafik Scatterplots (Priyatno, 2016).

Koefisien determinasi adalah kemampuan variabel $X$ (variabel independen) mempengaruhi variabel $Y$ (variabel terikat). Semakin besar koefisien determinasi menunjukkan semakin baik kemampuan X menerangkan Y. (Suharyadi, 2016, p162). Kemudian menurut Priyatno (2016, p97), koefisien determinasi digunakan untuk mengetahui prosentase sumbangan pengaruh variabel independen (variabel $\mathrm{X}$ ) secara bersama-sama terhadap variabel dependen (variabel Y). untuk uji hipotesis yang dilakukan terdiri dari uji $\mathrm{T}$ untuk uji hipotesis parsial dan uji $\mathrm{F}$ untuk uji hipotesis simultan.

\section{HASIL DAN PEMBAHASAN}

Penelitian ini menggunakan data primer yang diperoleh dari penyebaran kuesioner Pengaruh Profesionalisme, Integritas, dan Fee Audit terhadap Kualitas Audit kepada auditor pada Kantor Akuntan Publik (KAP) yang berada di DKI Jakarta sesuai dengan yang tercatat dalam direktori IAPI. Proses penyebaran kuesioner dilaksanakan pada bulan April - Mei 2017, dimana bulan April 2017 merupakan bulan sibuk auditor. Hal ini menyebabkan kuesioner yang disebar tidak dapat semuanya dikembalikan kepada peneliti. Oleh karena itu, jumlah keseluruhan responden adalah 177 orang dengan Kantor Akuntan Publik (KAP) yang menjadi sampel sebanyak 41 Kantor Akuntan Publik (KAP), yang terdiri dari 16 KAP di Jakarta Pusat, 8 KAP di Jakarta Selatan, 6 KAP di Jakarta Barat, 6 KAP di Jakarta Timur, dan 5 KAP di Jakarta Utara, dari 240 kuesioner yang disebar pada 48 Kantor Akuntan Publik (KAP) yang terdapat di wilayah DKI Jakarta.

Responden terdiri dari 115 orang berjenis kelamin laki-laki dan 62 orang berjenis kelamin perempuan. Pendidikan yang telah ditempuh responden pada penelitian ini adalah sebanyak 5 orang telah menyelesaikan pendidikan di tingkat Diploma IV (D4), 155 orang di tingkat S1, 17 orang telah menyelesaikan pendidikan di tingkat S2, dan tidak ada Sedangkan dari 177 responden, tidak ditemukan satupun responden yang telah mencapai tingkat pendidikan di tingkat Doktoral (S3). Hal tersebut terjadi karena penyebaran kuesioner dilakukan pada bulan April - Mei, dimana bulan April merupakan bulan sibuk bagi para auditor, sehingga mayoritas responden yang mengisi kuesioner adalah senior auditor yang sedang berada dikantor dengan mayoritas pendidikan terakhirnya adalah Strata-1 (S1), sedangkan para jajaran diatasnya tidak dapat ditemui karena sedang melakukan audit di tempat klien.

Jabatan yang dimiliki responden mayoritasnya adalah senior sebanyak 151 responden, 13 responden sebagai supervisor, 6 responden memangku jabatan sebagai 
manager, dan 7 responden yang memangku jabatan sebagai partner. Sementara dari sisi pengalaman responden, terdapat 87 responden memiliki pengalaman 2-5 tahun, 41 responden dengan pengalaman $<2$ tahun, sebanyak 37 responden memiliki pengalaman 510 tahun, dan responden yang memiliki pengalaman $>10$ tahun adalah sebanyak 12 responden. Kemudian dari segi usia responden, mayoritasnya ada di kisaran umur 25-30 tahun yaitu sebanyak 83 responden, 18-25 tahun sebanyak 60 responden, 24 responden yang memiliki umur di kisaran 30-40 tahun, dan hanya 10 responden dengan umur $>40$ tahun.

Hasil Analisis Data. Alat analisis yang digunakan dalam penelitian ini adalah analisis regresi linier berganda. Sebelum melakukan pengujian regresi, terdapat beberapa asumsi yang harus dipenuhi agar data yang akan dimasukkan dalam model regresi telah memenuhi syarat dan ketentuan dalam regresi. Uji asumsi klasik dalam penelitian ini mencakup uji normalitas, uji multikolinearitas, dan uji heteroskedastisitas. Uji normalitas bertujuan untuk mengukur apakah data kita memiliki distribusi normal sehingga dapat dipakai dalam statistik parametik, jika data tidak berdistribusi normal dapat dipakai statistik non parameti (Sujarweni, 2014, 102). Terdapat banyak metode untuk dapat melakukan uji normalitas, tetapi pada penelitian ini uji normalitas yang dilakukan menggunakan metode grafik normal $P-P$ plot. Berikut gambar hasil perhitungan uji normalitas yang diolah dengan menggunakan SPSS 22:

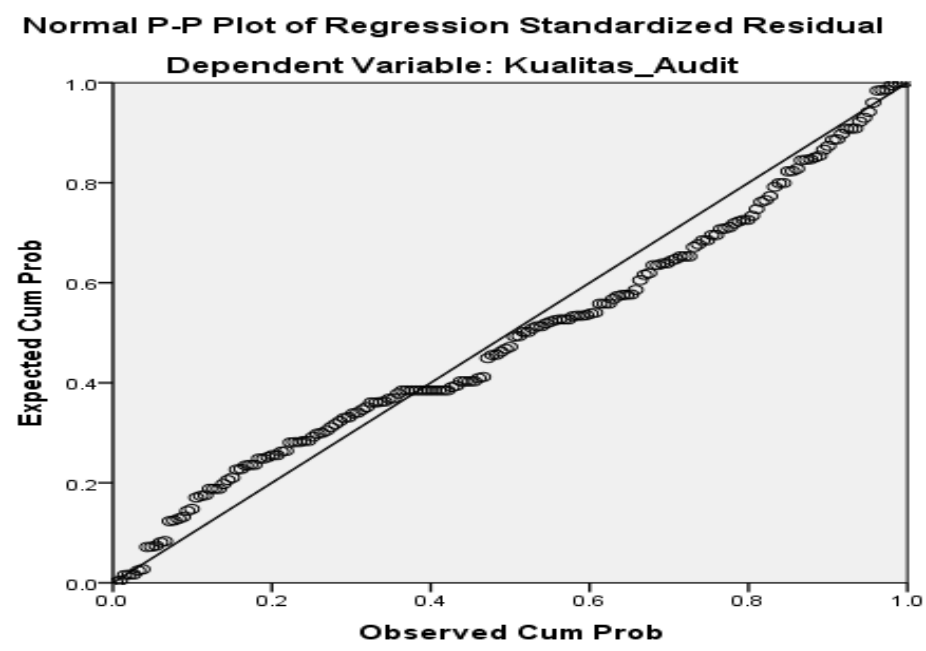

Gambar 2. Hasil Uji Normalitas

Sumber: Hasil olahan SPSS 22 (2017)

Kemudian untuk uji multikolinieritas dilakukan dengan melihat nilai tolerance dan Variance Inflation Factor (VIF) pada model regresi. Menurut Priyatno (2016, p116), apabila nilai VIF kurang dari 10 dan Tolerance lebih dari 0,1 maka dinyatakan bebas dari multikolinieritas atau tidak terjadi multikolinieritas. Pada hasil pengujian, angka Tolarance dari variabel bebas profesionalisme, integritas, dan fee audit mempunyai nilai lebih dari 0,1 yakni sebesar 0,644; 0,658; dan 0,785. Kemudian nilai Variance Inflation Factor (VIF) tidak lebih dari 10, yakni sebesar 1,552; 1,519; dan 1,273. Dengan demikian, dapat 
disimpulkan bahwa dalam model regresi tidak terjadi multikolinieritas antar variabel bebas.

Untuk uji heteroskedastisitas dilakukan pengujian dengan menggunakan metode Spearman's rho dan grafik Scatterplot. Pada metode Spearman's rho memberi hasil output bahwa korelasi antara variabel independen (profesionalisme, integritas, dan fee audit) dengan Unstandardized Residual memiliki nilai signifikansi (sig 2-tailed) lebih dari 0,05, yakni profesionalisme sebesar 0,445, integritas sebesar 0,438, dan fee audit sebesar 0,579. Karena signifikansi lebih besar dari 0,05, maka dapat disimpulkan bahwa tidak terjadi masalah heteroskedastisitas. Kemudian, untuk metode grafik Scatterplot, menghasilkan pola yang tidak jelas di atas dan di bawah angka 0 pada sumbu Y sehingga tidak terjadi masalah heteroskedastisitas.

Selanjutnya, uji regresi linier berganda digunakan untuk mengetahui pengaruh antara dua atau lebih variabel independen dengan satu variabel dependen yang ditampilkan dalam bentuk persamaan regresi (Priyatno, 2016, p92). Variabel independen dalam penelitian ini adalah Profesionalisme (X1), Integritas (X2), dan Fee Audit (X3), dan variabel dependennya adalah Kualitas Audit (Y). Untuk mempermudah pembacaan hasil dan interpretasi regresi maka digunakan bentuk persamaan. Persamaan atau model tersebut berisi konstanta dan koefisien regresi yang didapat dari hasil pengelolaan data dengan bantuan program SPSS 22 yang disesuaikan dengan persamaan regresi. Adapun hasil uji regresi linier berganda sebagai berikut:

Tabel 1. Hasil Uji Regresi Linier Berganda

\begin{tabular}{|c|c|c|c|c|c|}
\hline \multicolumn{6}{|c|}{ Coefficients $^{\mathrm{a}}$} \\
\hline & $\begin{array}{r}\text { Uns } \\
\mathrm{Co}\end{array}$ & $\begin{array}{l}\text { ardized } \\
\text { cients }\end{array}$ & $\begin{array}{l}\text { Standardized } \\
\text { Coefficients }\end{array}$ & $\mathrm{T}$ & Sig. \\
\hline Model & B & Std. Error & Beta & & \\
\hline 1 (Constant) & 6.348 & 2.495 & & 2.544 & .012 \\
\hline PROFESIONALISME & .583 & .081 & .466 & 7.220 & .000 \\
\hline INTEGRITAS & .346 & .077 & 287 & 4.489 & .000 \\
\hline FEE AUDIT & .133 & .065 & .120 & 2.051 & .042 \\
\hline
\end{tabular}

Berdasarkan tabel diatas, telah diperoleh hasil dari koefisien regresi, maka dapat dibuat suatu persamaan regresi sebagai berikut:

Model dalam penelitian ini adalah:

$$
\begin{aligned}
& \mathrm{Y}=\alpha+\beta 1 \mathrm{PROF}+\beta 2 \mathrm{INT}+\beta 3 \mathrm{FEE}+\epsilon \\
& \mathrm{Y}=6,348+0,583 \mathrm{PROF}+0,346 \mathrm{INT}+0,133 \mathrm{FEE}+\epsilon
\end{aligned}
$$

Pada persamaan regresi diatas, nilai konstanta tercantum sebesar 6,348. Hal ini dapat diartikan jika variabel bebas (independent) dalam model persamaan yakni profesionalisme, integritas, dan fee audit dianggap atau diasumsikan sama dengan bernilai 0 (nol), maka secara rata-rata variabel yang diukur akan meningkatkan kualitas audit 
sebesar 6,348 satuan. Besarnya pengaruh tiap-tiap variabel independen terhadap variabel dependen adalah sebagai berikut:

a. Koefisien regresi variabel profesionalisme (X1) menunjukkan nilai sebesar 0,583. Artinya pada penelitian ini, variabel profesionalisme berpengaruh terhadap kualitas audit. Hal ini menunjukkan bahwa ketika variabel profesionalisme mengalami peningkatan sebesar satu satuan, maka variabel kualitas audit juga akan mengalami peningkatan sebesar 0,583 satuan dengan catatan variabel lainnya dianggap konstan (tetap).

b. Koefisien regresi variabel integritas (X2) menunjukkan nilai sebesar 0,346. Artinya pada penelitian ini, variabel integritas berpengaruh terhadap kualitas audit. Hal ini menunjukkan bahwa ketika variabel integritas mengalami peningkatan sebesar satu satuan, maka variabel kualitas audit juga akan mengalami peningkatan sebesar 0,346 satuan dengan catatan variabel lainnya dianggap konstan (tetap).

c. Koefisien regresi variabel fee audit (X3) menunjukkan nilai sebesar 0,133. Artinya pada penelitian ini, variabel fee audit berpengaruh terhadap kualitas audit. Hal ini menunjukkan bahwa ketika variabel fee audit mengalami peningkatan sebesar satu satuan, maka variabel kualitas audit juga akan mengalami peningkatan sebesar 0,133 satuan dengan catatan variabel lainnya dianggap konstan (tetap).

Uji koefisien determinasi $\left(\mathbf{R}^{\mathbf{2}}\right)$ bertujuan untuk mengukur seberapa jauh kemampuan variabel $\mathrm{X}$ atau variabel independen dapat mempengaruhi variabel $\mathrm{Y}$ atau variabel terikat (Suharyadi, 2016, p162).. Berikut hasil uji Koefisien Determinasi $\left(\mathbf{R}^{2}\right)$ :

Tabel 2. Hasil Uji Koefisien Determinasi $\left(\mathbf{R}^{2}\right)$

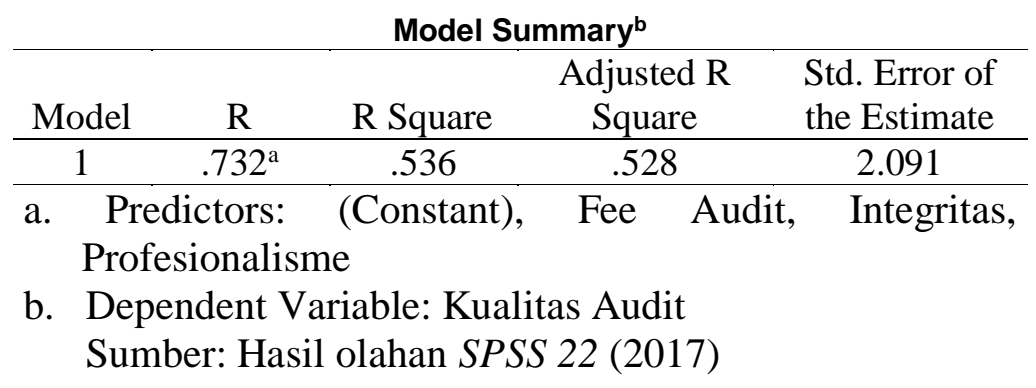

Berdasarkan Tabel 2 diatas, menyatakan bahwa nilai koefisien determinasi yang sudah disesuaikan (Adjusted $R$ Square) adalah 0,528. Hal ini berarti 52,8\% variasi variabel dependen yakni kualitas audit dapat dijelaskan oleh variasi variabel independen yakni profesionalisme, integritas, dan fee audit, sedangkan sisanya sebesar (100\% - 52,8\%) 47,2\% dijelaskan atau dipengaruhi oleh variabel lain diluar variabel pada penelitian ini.

Terakhir, yaitu uji hipotesis yang terdiri dari uji T parsial dan uji $\mathrm{F}$ simultan.

Uji T parsial menunjukkan seberapa jauh pengaruh variabel bebas (variabel independen) secara individual dalam menerangkan variabel terikat (variabel dependen) dan digunakan untuk mengetahui ada atau tidaknya pengaruh masing-masing variabel independen secara individual terhadap variabel dependen yang diuji yaitu antara variabel profesionalisme terhadap kualitas audit, integritas terhadap kualitas audit, dan variabel fee audit terhadap kualitas audit. Pengujian dilakukan dengan menggunakan tingkat signifikansi 0,05 dengan 
2 sisi, dan dengan membandingkan jika $-\mathrm{t}$ tabel $\leq \mathrm{t}$ hitung $\leq \mathrm{t}$ tabel, maka Ho diterima, dan jika -t hitung < - t tabel atau t hitung > t tabel, maka Ho ditolak (Priyatno, 2016, p9798). Berikut hasil uji T (parsial) sebagai berikut:

Tabel 3. Hasil Uji T Parsial

Coefficients $^{\mathbf{a}}$

\begin{tabular}{|c|c|c|c|c|c|}
\hline \multirow[b]{2}{*}{$\begin{array}{l}\text { Model } \\
\text { (Constant) }\end{array}$} & \multicolumn{2}{|c|}{$\begin{array}{l}\text { Unstandardized } \\
\text { Coefficients }\end{array}$} & \multirow{2}{*}{$\begin{array}{c}\text { Standardized } \\
\text { Coefficients }\end{array}$} & \multirow[b]{2}{*}{$\begin{array}{l}\mathrm{T} \\
2.544\end{array}$} & \multirow[b]{2}{*}{$\begin{array}{l}\text { Sig. } \\
.012\end{array}$} \\
\hline & $\begin{array}{l}\mathrm{B} \\
6.348\end{array}$ & $\begin{array}{r}\text { Std. Error } \\
2.495\end{array}$ & & & \\
\hline $\begin{array}{l}\text { PROFESIONALISM } \\
\text { E }\end{array}$ & .583 & .081 & .466 & 7.220 & .000 \\
\hline IN TEGRITAS & .346 & .077 & .287 & 4.489 & .000 \\
\hline FEE AUDIT & .133 & .065 & .120 & 2.051 & .042 \\
\hline
\end{tabular}

a. Dependent Variable: KUALITAS AUDIT

Sumber: Hasil olahan SPSS 22 (2017)

Untuk t tabel statistik pada signifikansi 0,05 dengan derajat kebebasan degree of freedom $(\mathrm{df})=(\mathrm{n}-\mathrm{k}-1)=177-3-1=173$, hasil yang diperoleh untuk t tabel sebesar 1,973. Berdasarkan tabel diatas, untuk variabel profesionalisme diperoleh nilai t-hitung sebesar 7,220 dengan signifikansi 0,000. Jadi, nilai t hitung > t-tabel $(7,220>1,973)$ dan signifikansi $<0,05(0,000<0,05)$, maka $\mathrm{Ho}_{1}$ ditolak, Ho ${ }_{1}$ diiterima. Jadi dapat disimpulkan bahwa profesionalisme berpengaruh terhadap kualitas audit. Untuk variabel integritas, diperoleh nilai t-hitung sebesar 4,489 dengan signifikansi 0,000. Jadi, nilai thitung > t-tabel $(4,489>1,973)$ dan signifikansi $<0,05(0,000<0,05)$, maka $\mathrm{Ho}_{2}$ ditolak, $\mathrm{Ho}_{2}$ diterima. Jadi dapat disimpulkan bahwa integritas berpengaruh terhadap kualitas audit. Kemudian untuk variabel fee audit, diperoleh nilai t-hitung sebesar 2,051 dengan signifikansi 0,042. Jadi, nilai t-hitung $>$ t-tabel $(2,051>1,973)$ dan signifikansi $<0,05$ $(0,042<0,05)$, maka $\mathrm{Ho}_{3}$ ditolak, $\mathrm{Ho}_{3}$ diterima. Jadi dapat disimpulkan bahwa fee audit berpengaruh terhadap kualitas audit.

Untuk uji $\mathrm{F}$ simultan, digunakan untuk mengetahui apakah secara simultan atau bersama-sama variabel independen berpengaruh atau tidak terhadap variabel dependen (Priyatno, 2016, p99-100). Hasil uji statistik F dapat menentukan hipotesis Ho ditolak atau diterima, jika nilai probabilitasnya lebih kecil dari 0,05, maka Ho ditolak Ha diterima. Berikut hasil uji F simultan.

Berdasarkan Tabel 4 diatas, dapat dilihat hasil uji $\mathrm{F}$ memberi nilai $\mathrm{F}$ hitung sebesar 66,592 dengan signifikansi 0,000, sedangkan $\mathrm{F}$ tabel sebesar dengan degree of freedom $(\mathrm{df} 1)=4-1=3$ dan $(\mathrm{df} 2)=(\mathrm{n}-\mathrm{k}-1)=177-3-1=173$ dan nilai signifikansi 0,05. Sehingga dapat disimpulkan bahwa $\mathrm{F}$ hitung $>$ F-tabel $(66,592>2,66)$ dan signifikansi $<0,05$ $(0,000<0,05)$, maka $\mathrm{Ho}_{4}$ ditolak $\mathrm{Ha}_{4}$ diterima sehingga dengan kata lain bahwa profesionalisme, integritas, dan fee audit berpengaruh secara simultan (bersama-sama) terhadap kualitas audit.

Interpretasi Data. Dalam penelitian ini, didapat nilai koefisien determinasi $\left(\mathbf{R}^{2}\right)$ sebesar $52,8 \%$. Sehingga dapat dikatakan bahwa profesionalisme, integritas, dan fee audit mempengaruhi kualitas audit sebesar 52,8\%, sementara sisanya dijelaskan atau dipengaruhi oleh variabel lain diluar variabel pada penelitian ini. 
Tabel 4. Hasil Uji F Simultan

\begin{tabular}{llrrrrr}
\hline \multicolumn{7}{c}{ ANOVA $^{\mathbf{a}}$} \\
Model & & Sum of & & & & \\
\hline 1 & Squares & Df & Mean Square & \multicolumn{1}{c}{ F } & \multicolumn{1}{c}{ Sig. } \\
\hline & Regression & 873.288 & 3 & 291.096 & 66.592 & $.000^{\mathrm{b}}$ \\
& Residual & 756.238 & 173 & 4.371 & & \\
& Total & 1629.525 & 176 & & & \\
\hline
\end{tabular}

a. Dependent Variable: KUALITAS AUDIT

b. Predictors: (Constant), FEE AUDIT, INTEGRITAS, PROFESIONALISME

Sumber: Hasil olahan SPSS 22 (2017)

Oleh karena hasil analisa data diatas, maka didapatlah hasil pengujian hipotesis secara keseluruhan seperti berikut ini:

Tabel 5. Hasil Pengujian Hipotesis Keseluruhan

\begin{tabular}{clc}
\hline Hipotesis & \multicolumn{1}{c}{ Pernyataan } & Hasil \\
\hline $\mathrm{H}_{1}$ & $\begin{array}{l}\text { Profesionalisme berpengaruh } \\
\text { terhadap kualitas audit }\end{array}$ & Diterima \\
$\mathrm{H}_{2}$ & $\begin{array}{l}\text { Integritas berpengaruh terhadap } \\
\text { kualitas audit }\end{array}$ & Diterima \\
$\mathrm{H}_{3}$ & $\begin{array}{l}\text { Fee Audit berpengaruh terhadap } \\
\text { kualitas audit }\end{array}$ & Diterima \\
$\mathrm{H}_{4}$ & $\begin{array}{l}\text { Profesionalisme, Integritas, dan Fee } \\
\text { Audit secara simultan berpengaruh } \\
\text { terhadap kualitas audit }\end{array}$ & Diterima \\
\end{tabular}

Sumber: Hasil olahan Peneliti (2017)

Pengaruh Profesionalisme (X1) terhadap Kualitas Audit (Y). Berdasarkan hasil analisis data penelitian yang telah peneliti uraikan diatas, terdapat pengaruh porfesionalisme terhadap kualitas audit secara parsial yang dibuktikan dengan nilai $\mathrm{t}$ hitung variabel profesionalisme sebesar 7,220 dengan signifikansi 0,000 yang artinya $t$ hitung $=7,220>\mathrm{t}$ tabel 1,973 dan signifikansi $0,000<0,05$. Sementara berdasarkan hasil uji regresi linier berganda, variabel profesionalisme menyumbang pengaruh sebesar $58,3 \%$ terhadap kualitas audit dimana jika variabel lain bernilai konstan (0), maka kualitas audit akan meningkat sebesar 58,3\%.

Hasil ini menunjukkan bahwa auditor yang dapat memegang teguh prinsip profesionalisme pada saat melaksanakan penugasan audit akan menghasilkan hasil audit yang baik dan berkualitas. Karena telah berdasarkan kepada kode etik profesi, dan telah sesuai dengan standar-standar yang berlaku secara umum seperti SPAP, ISA, sehingga dapat dipercaya dan diandalkan pada saat akan dipakai oleh pemakai laporan keuangan (pemangku kepentingan) untuk melakukan pengambilan keputusan.

Hal ini sejalan dengan penelitian Lesmana dan Nera (2015), menyatakan bahwa variabel profesionalisme berpengaruh terhadap kualitas audit, dikarenakan semakin tinggi 
tingkat profesionalisme yang dimiliki oleh auditor, maka akan semakin berkualitas hasil auditnya.

Hasil ini juga serupa dengan penelitian Fietoria dan Elisabeth Stefany Manalu (2016) yang menunjukkan bahwa variabel profesionalisme berpengaruh signifikan terhadap kualitas audit. Hal ini berarti, semakin tinggi tingkat profesionalisme yang dimiliki auditor akan berpengaruh dalam menghasilkan audit yang berkualitas. Sementara hasil ini tidak sejalan dengan hasil dari penelitian Putu Septiani Futri dan Gede Juliarsa (2014), yang menyatakan bahwa profesionalisme tidak berpengaruh terhadap kualitas audit. Hal ini berarti jika sikap profesionalisme yang dimiliki tinggi tidak menjamin bahwa kualitas audit akan baik.

Pengaruh Integritas (X2) terhadap Kualitas Audit (Y). Berdasarkan hasil analisis data penelitian yang telah peneliti uraikan diatas, terdapat pengaruh integritas terhadap kualitas audit secara parsial yang dibuktikan dengan nilai t hitung variabel integritas sebesar 4,489 dengan signifikansi 0,000, yang artinya t hitung 4,489>t tabel 1,973 dan signifikansi $0,000<0,05$. Sementara berdasarkan hasil uji regresi linier berganda, variabel integritas menyumbang pengaruh sebesar $34,6 \%$ terhadap kualitas audit dimana jika variabel lain bernilai konstan (0) maka, kualitas audit akan meningkat sebesar 34,6\%.

Hasil ini menunjukkan bahwa auditor yang memiliki sikap integritas yang tinggi akan menghasilkan kualitas audit yang baik. Karena kualitas audit yang dihasilkan telah dikerjakan dengan sikap konsistensi yang tinggi, sikap bebas dari konflik kepentingan dan mampu memegang rahasia klien, serta sikap berani, jujur, dan berterus terang. Jadi semakin tinggi sikap integritas yang dimiliki oleh seorang auditor, maka akan semakin baik dan kualitas audit yang dihasilkan oleh auditor tersebut.

Hal ini sejalan dengan penelitian Prasetyo dan Agus (2016), yang menyatakan bahwa variabel integritas berpengaruh terhadap kualitas audit. Dengan demikian maka, semakin tinggi sikap integritas yang dimiliki oleh auditor tersebut, maka akan semakin tinggi atau semakin baik kualitas audit yang dihasilkan oleh auditor. Hal serupa juga ditemukan pada penelitian

Pengaruh Fee Audit (X3) terhadap Kualitas Audit. Berdasarkan hasil analisis data penelitian yang telah peneliti uraikan diatas, terdapat pengaruh fee audit terhadap kualitas audit secara parsial yang dibuktikan dengan nilai t hitung variabel fee audit sebesar 2,051 dengan signifikansi 0,042, yang artinya t hitung 2,051 > t tabel 1,973 dan signifikansi $0,042<0,05$. Sementara berdasarkan hasil uji regresi linier berganda variabel fee audit menyumbang pengaruh sebesar $13,3 \%$ terhadap kualitas audit dimana jika variabel lain bernilai konstan (0) maka, kualitas audit akan meningkat sebesar 13,3\%.

Hasil ini menunjukkan bahwa penetapan fee audit yang terlalu tinggi dan terlalu rendah dapat berdampak terhadap kualitas audit yang dihasilkan oleh auditor, sehingga penetapan fee audit sebaiknya didasarkan kepada Standar Profesional Akuntan Publik (SPAP) yang berlaku secara umum. Dengan demikian, auditor dapat terhindar dan terbebas dari perbuatan yang dapat merusak citra profesi. Tinggi rendahnya besaran fee audit dapat dilihat dan dipengaruhi dari resiko penugasan, kompleksitas jasa yang diberikan, ukuran KAP (besar kecilnya KAP yang akan diaudit), struktur biaya KAP yang bersangkutan dan pertimbangan profesi lainnya.

Hal ini sejalan dengan penelitian yang dilakukan oleh Idawati (2014), menyatakan bahwa variabel fee audit berpengaruh terhadap kualitas audit. Hal ini dapat dijelaskan 
bahwa jika fee audit yang diberikan terlalu rendah atau terlalu tinggi, maka dapat menggangu kualitas audit auditor tersebut.

\section{Pengaruh Profesionalisme (X1), Integritas (X2), dan Fee Audit (X3) Secara}

Simultan terhadap Kualitas Audit (Y). Berdasarkan hasil analisis data penelitian melalui pengujian hipotesis yang telah peneliti uraikan diatas, dapat dilihat bahwa profesionalisme, integritas, dan fee audit berpengaruh secara simultan terhadap kualitas audit yang dibuktikan dengan nilai $\mathrm{F}$ hitung $>\mathrm{F}$ tabel $(66,592>2,66)$ dengan tingkat signifikansi sebesar $0,000<0,05$.

Auditor yang dapat memegang teguh prinsip profesionalisme akan memberikan hasil audit yang baik dan berkualitas, karena auditor telah patuh terhadap standar-standar yang berlaku secara umum, seperti SPAP, ISA, dan juga telah berdasarkan kepada kode etik. Kemudian, auditor yang memiliki sikap integritas yang tinggi pada saat melaksanakan penugasan audit akan menghasilkan kualitas audit yang baik dan dapat dipercaya, karena kualitas audit yang dihasilkan telah dikerjakan dengan sikap konsistensi yang tinggi, sikap bebas dari konflik kepentingan dan mampu memegang rahasia klien, serta sikap berani, jujur, dan berterus terang. Untuk fee audit, auditor harus menetapkan fee audit berdasarkan kepada Standar Profesi Akuntan Publik (SPAP) yang berlaku secara umum, sehingga auditor dapat terhindar dari perbuatan yang dapat merusak citra profesi. Penetapan fee audit yang terlalu tinggi dan rendah dapat menggangu sikap independensi auditor yang akan berdampak terhadap kualitas audit yang dihasilkan auditor tersebut.

\section{PENUTUP}

Simpulan. Berdasarkan hasil analisis, maka pada penelitian ini dapat disimpulkan bahwa: (1) Profesionalisme berpengaruh terhadap kualitas audit. Hal ini berarti semakin tinggi profesionalisme yang dimiliki auditor, maka akan semakin tinggi juga kualitas audit yang dihasilkan. (2) Integritas berpengaruh terhadap kualitas audit. Hal ini berarti, semakin tinggi sikap integritas yang dimiliki oleh seorang auditor, maka akan semakin baik dan kualitas audit yang dihasilkan oleh auditor tersebut. (3) Fee Audit berpengaruh terhadap kualitas audit. Hasil ini menunjukkan bahwa penetapan fee audit yang terlalu tinggi dan terlalu rendah dapat berdampak terhadap kualitas audit yang dihasilkan oleh auditor, sehingga penetapan fee audit sebaiknya didasarkan kepada Standar Profesional Akuntan Publik (SPAP) yang berlaku secara umum. Dengan demikian, auditor dapat terhindar dan terbebas dari perbuatan yang dapat merusak citra profesi. (4) Profesionalisme, Integritas, dan Fee Audit berpengaruh secara simultan terhadap kualitas audit. Hal ini berarti variabel independen sangat berpengaruh secara simultan terhadap variabel dependen.

\section{DAFTAR RUJUKAN}

Agoes, Sukrisno dan I Cenik, Ardana (2009). Etika Bisnis dan Profesi. Salemba Empat. Jakarta.

Agoes, Sukrisno dan I Cenik Ardana. (2013). Etika Bisnis dan Profesi, Tantangan Membangun Manusia Seutuhnya. Edisi Revisi. Jakarta: Salemba Empat

Arens, Alvin A., Elder, Randal J. Dan Beasley, Mark S. (2010). Auditing and Assurance Service. Pearson Education, Inc, New Jersey. 
Arens, A. A., Randal, J.E., Mark, S.B., \& Amir, A.J. (2011). Jasa Audit dan Assurance, Edisi Tiga Belas, Jilid Satu. New Jersey: Pearson Education.

Arens, Alvin A., Elder, Randal J. and Beasley, Mark S. (2012). Auditing and Assurance Service An Integrated Approach. Pearson Education, Inc, New Jersey.

Arens, A.Alvin, Randal. J. Elder, Marks S.Beasley. (2015). Auditing \& Jasa Assurance, Pendekatan Terintegrasi. Edisi kelimabelas. Buku 1. Jakarta: Erlangga.

Baotham, Sumintron. (2007). The Impact of Proffesional Knowledge and Personal Ethics on Audit Quality. International Academy Bisnis \& Ekonomi.

Beatty, R., P. (1989)."Auditor Reputation and The Pricing of Initial Public Offerings". The Accounting Review 64 (Oktober), 693-709.

Beattie, Vivien, Alan Goodacre, Ken Pratt and Joanna Stevenson. (2001). "The Determinants of Audit Fees - Evidence From The Voluntary Sector". Accounting and Bussiness Research. 31 (4), 243-274.

Behn, B.K., J.V, Carcello, and D.R.Hermanson. (1999). Client Statisfaction and Big 6 audit Fees. Contemporary Accounting Research 16(4), 587-608.

Besacier Nathalie Gonthier and Alin Schatt. (2007). "Determinants of Audit Fees for French Quoted fir". Managerail Audting Journal. 22 (2), 139-160.

Boo, El'Fred dan Hian Chey Koh. (2004). Are Client-Perceived Audit Firm Reputation and Audit Team Attributes Associated With BigN audit Fee? Working Papers on SSRN.

Bouhawia, S.Mohammed, Gugus Irianto, dan Zaki Baridwan. (2015). "The Effect of Working Experience, Integrity, Competence, and Organizational Commitment On Audit Quality (Survey State Owned Companies in Libya)". Journal of Economics and Finance, 6 (4), 60-67.

Boynton William C., Raymon N. Jhonson, Walter G. and Kell. (2006). Modern Auditing. $8^{\text {th }}$ Edition. USA. Richard D. Irwin Inc.

Carcello, J.V. R.H. Hermanson and N.T. Mc Grath. (1992). "Audit quality Attributes; The Perceptions of Audit Partner. Prepares and Financial statement Users". Auditing: A journal of Practice \& Theory. 11, 1-15.

De Angelo, Linda Elizabeth. (1981). "Auditor Size and Audit Quality". Journal of Accounting and Economics, 3, 183.-199.

Departemen Keuangan Republik Indonesia. 2008. Keputusan Menteri Keuangan Nomor 17/ KMK.01/2008 tentang Jasa Akuntan Publik.

Duft. 2004. Understanding Audit Quality: The View of Auditors, Auditee and Investor.Melalui http://aaahg.org/Am2005/display.cfm?filename

Etteredge, Michael L., Chan Li, and Susan Scholz. (2007). "Audit Fees and Auditor Dismissals in The Sarbanes Oxley Era". Accounting Horizon, 21 (4), 371-386.

Friska, Novanda. (2012). "Pengaruh Profesionalisme Auditor, Etika Profesi Dan Pengalaman Auditor Terhadap Pertimbangan Tingkat Materialitas". Skripsi, Fakultas Ekonomi Universitas Negeri Yogyakarta.

Gerrald, lain, Hougton 1 and B Keith. (1994). "Audit Fee:The Effect of Auditee, Auditor and Industry Diffrence". Managerial Auditing Journal. 9, 3-9

Hay. David and David Davis. (2002). "The Voluntary Choice of An Audit of Any Level of Quality: Auditing”, A Journal of Practice and Theory. 23.

Heyrani, Forough, Bahman Banimahd, Fereydoun Rahnamayeh Roudposhti. (2015). "Investigation of Effect of Auditor's Professionalism Levels on Their Judgement to 
Resolve the Conflict between Auditor and Management. "Department of Accounting, Science and Research Branch, Islamic Azad University, Tehran, Iran. “ 177-188.

Institut Akuntan Publik Indonesia. (2011). Standart Profesional Akuntan Publik. Jakarta: Salemba Empat.

Jackson, Andrew B. Molderich, Michael and Roebuck, Peter. (2008). "Mandatory Audit

Firm Rotation and Audit Quality". Managerial Auditing Journal, 23 (5), 420-437.

Jubb, C.A, Houghton K.A, and Butterwort, S. (1996). "Audit Fee Determinant: The Plural

Nature of Risk". Mangerial Auditing Journal. 25-40.

Lee, Hoseuop. (2004). Effect of Sarbanes Oxley Act and SEC Final Ruling on Auditor Independence. Accounting Research, Working Papers Series, SSRN, February 2004.

Lesmana, Rudi dan Nera Marinda Machdar. (2015). "Pengaruh Profesionalisme, Kompetensi, dan Independensi Auditor Terhadap Kualitas Audit". Jurnal Akuntansi,

Fakultas Ekonomi Institut Teknologi dan Bisnis Kalbis, 2 (1), 33-40.

Meidawati, N. (2001). Meningkatkan Akuntabilitas Auditor Independen Melalui Standar Profesional. Media Akuntansi, 16:IX-XVI.

Mills, David. (1993). Quality Auditing. First Edition. Capman and Hall. LOndong UK.

Missier, Glover, Prawitt. (2006). Auditing and Assurance Service Asystematic Approach.

The McGraw-Hill Companies, Inc.

Mulyadi (2002). Auditing EdisiPertama.SalembaEmpat. Jakarta

Mulyadi. (2011). Auditing. Jakarta: Salemba Empat.

Palmrose, Z., (1984). "The demand for Quality Differentiated Audit Service in an Agency

Cost Setting: An Empirical Investigation". Auditing Research Symposium, 229-252.

Prasetyo, Danang Febri dan Agus Endro Suwarno. (2016). "Pengaruh Independensi, Kompetensi, Integritas, Objektivitas, dan Pengalaman Kerja Terhadap Kualitas Audit (Studi pada Kantor Akuntan Publik di JawaTengah)". Jurnal Fakultas Ekonomi dan Bisnis, Universitas Muhammadiyah Surakarta, 3, 578-588.

Priyatno, Duwi. (2016). Spss Handbook. Analisi Data, Olah Data, \& Penyelesaian KasusKasus Statistik. Yogyakarta: MediaKom.

Samelson, Donald, Suzanne Lowensohn and Laurance E Jhonson. (2006). "The Determinants of Percieved Audit Quality and Auditee Satisfaction in Local Government”. Journal of Public Bugeting, Accounting \& Financial Management, pg.139-166.

Schoeroeder M. S.J. Salamon and D,W, Vickey. (1986). "Audit Quality: The Perseption Audit Committee, Chairperson and Audit Partners". Auditing: A Joutnal Practice and Theory. Vol. 13 Supplement.

Sihotang, Kasdin. (2016). Etika Profesi Akuntansi. Yogyakarta: PT Kanisius

Simunic, D. A. (1980). "Pricig of Audit Service: Theory and Evidence". Journal of Accounting Research 18 (Spring), 161-190.

Sukriah, A., dan Inapty, B.A. (2009). "Pengaruh Pengalaman Kerja, Independensi, Objektivitas, Integritas, dan Kompetensi Terhadap Kualitas Hasil Pemeriksaan". Simposium Nasional Akuntansi XII. 3-9 November 2009, Palembang, Indonesia. Hal $1-10$.

Suharyadi , Purwanto S.K. (2015). Statistika untuk Ekonomi dan Keuangan Modern. Edisi 2. Buku 2. Jakarta: Salemba Empat.

Sujarweni, V.W. (2014). Metodologi Penelitian: Lengkap, Praktis, dan Mudah Dipahami. Yogyakarta: Pustaka Baru Press. 
Surat Keputusan Ketua Umum Institute Akuntan Publik Indonesia No: Kep / 24/ IAPI/VII/. 2008. Tentang Kebijakan Penentuan Fee Audit Dalam Menetapkan Imbalan Jasa.

Stanley Jonathan D, dan Tood DeZoort, (2007). "Audit Firm Tenure and Finanzial Restatement: An Analysis of Industry Specialization and Fee Effects". Journal of Accounting and Public Policy, 26, 131-159

Turpen, Richard A. (1995). "Audit fees-what research tell us," The CPA Journal online. $12(1), 54-56$.

Wallace, W. A., (1980). "The Economic Role of the Audit in Free and Regulated Markets, Touche Ross \& Co. aid to Education Program". Journal of Accounting Literature, 23, 153-193.

Yendrawati, R. (2008). “Analisis Hubungan antara Profesionalisme Auditor dengan pertimbangan Tingkat Materialitas dalam Proses Pengauditan Laporan Keuangan. Fenomena, 6 (1) Maret. 